\title{
PLATÃO E A CIDADE JUSTA: POETAS ILUSIONISTAS E POTÊNCIAS DA ALMA
}

\author{
Rachel Gazolla* \\ rachelgazolla@gmail.com
}

RESUMO A censura que Platão faz à poesia na República apresenta dois ângulos que serão investigados neste texto: de um lado, a relação com a mímesis, considerada como necessária para o conhecimento pela via da phantasía; de outro, a relação do gênero epithymético da alma, com a crítica mais específica exposta no livro $X$.

Palavras-chave Poesia; Imitação; Phantasía; Conhecimento.

ABSTRACT The censorship Plato directs against poetry in the Republic is investigated from two points of view in this article: on one hand, the perspective of mimesis, which is seen as necessary to achieve knowledge, through phantasía; on the other, the issue of the epithymetic genre of soul, which is part of the more specific criticism developed in book X.

Keywords Poetry; Imitation; Phantasía; Knowledge.

\section{A questão}

Há uma passagem da República (595a) que interessa para iniciar esta investigação: quando Sócrates diz que não se deve admitir os poetas na sua

* Professora de História da Filosofia Antiga na PUC-SP, Brasil. Artigo recebido em julho de 2007 e aprovado em outubro de 2007. 
cidade justa sem alguma censura. Ele diz: “(...) de modo algum "poesia enquanto mimética. Não admiti-la absolutamente é, como me parece, claro, desde que colocamos e separamos cada uma das formas da alma". Poderse-ia escolher outro diálogo e outros momentos para desenvolver a questão da crítica à mimética poética (pois há sua aceitação no Íon), mas nos limites desse texto já há bons indícios da pretensão do filósofo ao refletir sobre essa técnica e seu resultado para a vida prática. Ao mesmo tempo em que o mýthos encanta Platão e ele o rechaça quando referido à paidêutica, há ainda o ângulo da falsidade do conhecimento poético que necessita de esclarecimentos, pois se o falso fosse um ponto importante na crítica do filósofo, a Verdade deveria acompanhar a educação dos homens, o que ele mesmo, Platão, não faz na sua cidade justa. A poesia não acompanha a verdade, no entanto, pelo ângulo estético ela é venerável pela fruição que produz. Como exigir uma "verdade poética?"

A bem dizer, o belo que se pressupõe acompanhar a poesia não necessariamente se atrela à verdade, mas não dispensa o Bem, de modo que é preciso enquadrar a crítica platônica em função daquilo sobre o que o filósofo se propõe a refletir em cada diálogo; e na República, procura o conhecimento da verdade e justiça para a boa formação dos cidadãos. Ora, a poesia tanto é dita uma arte (téchne) como uma potência divina (theía dýnamis), então, qual o fundamento da ação do poeta como technikós que produz para os homens, em se considerando uma cidade justa? Por que ele deve ser censurado se dele necessitamos? Lemos no livro II que o saber poético é mimético e está no campo da Mousiké; que é uma produção sujeita à censura parcial porque não é diégesis (descrição - Rep. 392a et seq.), e, efetivamente, a poesia não o é, mesmo aquela que pretende ensinar. Toda téchne sendo mímesis (e também a força divina recebida pela via da mania é uma espécie de mímesis, o que não analisarei nesta ocasião) não deixa de ressoar naquele que ouve de modo mimetizado, uma afirmação mais complexa a ser vista.

Há que verificar os sentidos que Platão quis dar à poietiké mimetiké, ao menos em parte, e qual a especificidade da poesia stricto sensu como produção da linguagem não descritiva e imitativa ilusória em sentido propriamente platônico). Parece não ser à técnica que se dirige a censura de Platão, nem à mímesis - e nem poderia fazê-lo, pois que as usa -, mas ao modo de usá-las. Tanto as técnicas em geral como a poesia em particular implicam em movimentos específicos da alma comprometidos com suas potências específicas: o aisthetón (sensível) provoca um páthos em nós, uma afecção, e será recebido pelo aistheteríos, os sentidos, e uma aísthesis, uma sensação, se produz; há phantasía como potência que retém as sensações na forma de 
aparecimentos anímicos, ou visões (phainómena) anímicas, ponto importante na reflexão platônica; há o logistikón como potência pensante e discursiva que tem íntimo parentesco com a phantasía, como será analisado. Por que o filósofo critica a mimética poética especificamente na República, e qual a relação dessas potências anímicas com tal crítica?

\section{Ser e fazer}

Mimetizar depende de paradigmas a partir dos quais uma ação se desdobra em processo de produção (téchne). Platão evidencia isso na própria técnica imitativa que usa para a construção da Politéia justa, ela mesma paradigmática para possíveis homens justos. Assim, é preciso, a priori, que haja um degrau oculto no pensamento de quem a constrói: a boa medida e a boa proporção que acompanham a própria idéia de justiça a ser explicitada dialogicamente. $\mathrm{O}$ modelo está na posse do demiurgo, do contrário sua ação produtora se daria ao acaso, avançando, recuando, sem clareza quanto ao próprio processo, porque sem modelo. Dificilmente teria excelência, conforme Platão, e se tivesse seria por acaso (Rep. II e III).

Já no livro I, o filósofo leva o diálogo sobre a justiça a um impasse, e de modo astucioso cria a exigência lógica de um paradigma com o fim de saber o que é justiça na cidade e em cada um. Estabelece, assim, uma téchne, e como demiurgo de palavras bem encadeadas e imagens persuasivas para tal construção, vai tecendo seu lógos argumentativo, que apresenta fortemente um aspecto "técnico-poiético" desde o início da construção. O objetivo é o de produzir pensamentos com imagens para que o discípulo acompanhe, passo a passo, a construção, transformando o movimento inicial de sua alma quanto ao tema proposto (a justiça). Sabe-se que as técnicas não se perguntam sobre o que é aquilo que fazem, como Sócrates apontara na Apologia, e se o diálogo é também uma "arte teatral" - em que um dialogante especial (ou leitor) se acomoda para o aprendizado à força das imagens faladas (eídola legóumena) -, há uma diferença quanto ao processo de produção de um artefato e produção de discursos. Então, duas perguntas podem ser feitas ao próprio produzir: (a) pergunta-se sobre o ser de algo que se vai produzir ("o que é?"); (b) ou sobre "como se faz?"

A primeira pergunta é especificamente filosófica e dirige o leitor para além das técnicas, como fará Platão mesclando técnica e dialética como epistéme. Nesse movimento de conhecimento, chegará à crítica à poesia, $\mathrm{o}$ que, a meu ver, não se deve ao fato de os poetas imitarem ou serem técnicos e não filósofos, e nem porque eles não se importam se o que dizem é verdadeiro 
ou falso - algo que não se pode exigir de quem não pretende ser filósofo -, mas ao fato de a poesia ser produzida de certo modo e passada aos seus receptores sem que o poeta saiba sobre o que provoca, emocional e praticamente.

\section{1}

No livro II da República, Platão propõe a Glauco e Adimanto pensarem o que é a justiça para um conjunto de cidadãos, para entender o que ela é em cada um. Há dificuldades após o combate de logoí entre Sócrates e Trasímaco, e a Politéia se inicia com a proposta socrática de buscar o que é a justiça por meio, primeiramente, de imagens amplas (as letras maiúsculas). A senha está posta ao leitor: um técnico sempre fabricará algo e terá uma forma-imagem anterior na sua alma, na qual fixará o olhar enquanto exerce seu trabalho de criação do produto. Esse é o processo técnico. A "visão" demiúrgica será de uma só coisa em todas as suas partes. E não é isenta de astúcia a proposta platônica ao usar o exemplo das letras, uma vez que, como anuncia no Crátilo (422e), imitar é dar sentido a algo, é assinalar, sinalizar (semaínein) algo de algo, e um exemplo imagético faz isso, e quanto mais claro ele for (letras maiúsculas), melhor.

No caso dessa Politéia justa, é por meio de imagens de coisas e palavras que o Sócrates técnico buscará o que é a justiça, e tem, de antemão, a formaimagem dela, mas o discípulo não tem. Se Platão mimetiza sua cidade e ao mesmo tempo critica aquele que mimetiza os deuses em imagens faladas - os poetas -, só o faz porque sabe até onde pode levá-lo tal imitação nesse primeiro grau, havendo outros que serão expostos no livro $\mathrm{X}$, como se sabe, relativos, no entanto, ao ângulo verdade-falsidade. A pergunta que o move para a demiurgia inicial é "o que é a justiça?", e só depois, "como praticá-la no campo técnico?". Ele aceita a astúcia técnico-persuasiva para chegar a um fim nesse primeiro momento da reflexão, e segue na busca do que ela é na exposição de argumentos, em ajuste com a estrutura que busca edificar (Rep. II e III). Ademais, uma cidade justa en lógos permite imitar no mesmo grau de falsidade do poeta, que, no livro X, receberá duras críticas, como é o caso do mito das raças proposto, sem pejo, por Sócrates no livro III.

A censura à mimética poética está bem mais descritiva nos primeiros livros e refletida no livro X, porque é preciso explicitar primeiro as "formas da alma" (o epithymetikón, o thymoediés, o logistikón) para, só depois, verticalizar a pretendida crítica.

Dependente de ícones, o técnico-filósofo do lógos adentrará em labirintos, passará por claridades e sombras, uma vez que o bom demiurgo não prescinde de habilidades para criar seu produto, nem desse solo primeiro que é o 
conhecimento da forma-imagem para o processo de produção. Se não fosse a pergunta “o que é a justiça?', a cidade de Sócrates estaria completa ao término de sua edificação pela via das imagens faladas (livros IV-V), pois responde ao "como se faz uma cidade justa?". No entanto, vai além, porque é estruturada a partir do que é a justiça nela mesma, o que só é possível explicitar com a apresentação da teoria da alma tripartida, suas funções, seus ajustes com as instituições cívicas e tendências de cada cidadão. Por isso, no livro X, é possível criticar a mimética poética plenamente, tendo em mãos as três dynámeis da alma já expostas.

\section{2}

Qualquer bom técnico não precisa ir "além" - sejam sapateiros, padeiros, médicos ou matemáticos - e não dispensa a medida e proporção para seus produtos, o ajuste entre as partes da coisa, porém, só necessita saber como trabalhar. Sequer o matemático se pergunta sobre o que é o número, a medida, a proporção, as grandezas e a justeza enquanto eles mesmos, apesar de aprenderem a usá-los (509a et seq.). Saber fazer é uma excelência. No entanto, o campo do poieîn é restrito para o filósofo. Não se pode dispensar a Utilidade das técnicas (e da poesia especificamente), mas é preciso indagar sobre o Ser e a Verdade. Abre-se um feixe complexo para reflexão quanto ao que é útil, ao que é verdadeiro, ao que é justo e seus contrários. No caso da imitação, em se tratando do par eidolon-paradeigma, o feixe aumenta de tamanho na medida em que a noção de verossimilhança entra em jogo. Em 377a da República, diz Platão: "não compreendes (...) que primeiro dizemos mitos às crianças? Ora, todo esse conjunto, em realidade, resulta falso, embora com alguma verdade. Nós nos servimos de mitos para as crianças antes de enviá-las ao ginásio". Esse conjunto - os mitos - tem que sofrer as devidas separações para que surja o conhecimento das partes, e uma dessas partes é a poesia.

O mýthos como palavra imagética é verossímil porque tem algo de semelhante (homoiós) ao modelo de que éimagem. Aquestão daverossimilhança é indicada sem qualquer tom pejorativo no Sofista, como se sabe, no passo 240a-b, quando Teeteto afirma ao estrangeiro que, sobre a imagem (eídolon), ela provavelmente quer dizer uma outra coisa que o modelo, semelhante a ele, e pergunta o que é imagem. O estrangeiro volta-lhe a pergunta:

\footnotetext{
E - Esse outro (o modelo) dizes tal como o verdadeiro, ou algo segundo ele?

$\mathrm{T}$ - Não completamente verdadeiro, mas semelhante.

E - Mas por verdadeiro entendes o que realmente é (óntôs ón)?

$\mathrm{T}$ - Realmente.

$\mathrm{E}-(\ldots)$ o não verdadeiro é contrário ao verdadeiro? (...)

$\mathrm{T}$ - Como não!
} 
E - Não ser realmente (ouk óntôs) dizes não ser (ouk ón), então, o semelhante (tò eoikós), e todavia, o afirmas não verdadeiro.

$\mathrm{T}$ - Mas é algo.

E - Não verdadeiramente, disseste.

T - Seguramente, não; ainda que realmente semelhante (eikòn óntôs).

Exposto está o peso da semelhança, e na República não há porque dispensar os eidola. No mýthos, é preciso alcançar o que há nele de verossímil e de não-verossímil, se assim quiser o construtor da República. Ora, se falso é dizer uma coisa que não é como sendo, o grave está na afirmação de algo que não é e, mesmo assim, é dito ser, e não no fato da verossimilhança (muita ou pouca). Lembremos do modo irônico, mas não totalmente irônico, das famosas palavras de Sócrates no início do Fédon: que ele não é mitólogo mas que gostaria de ser, apesar de as musas o terem visitado em sonhos muitas vezes; adianta o que pensa ser aceitável na mousiké, campo sempre do verossímil. E dado que os técnicos sempre trabalham com a forma-imagem de algo a mimetizar no produto, quer seja um artefato, quer seja um discurso, não se trata de criticar a falta de alétheia na imitação, mas aceitar a verossimilhança que há nela, necessariamente.

Platão expõe sua preocupação quanto às intenções práticas do "músico" (meios e fins imbricados) e não quanto à possível falta de alétheia da mousiké: há que pensar não só para o que serve um produto, mas quais são seus fins últimos, sem o que não se sinaliza a areté ou não-areté do produtor. Esse é o caminho da poiésis à theoría: saber sobre o que é o que se faz. Ademais, mesmo havendo a preocupação quanto aos discursos sofísticos, para demonstrar, ao contrário do que eles pretendem, a existência do pseudós, não parece ser esse o foco para o problema da mimética, pois o próprio filósofo admite o uso do pseudós e dele se utiliza sempre que considera necessário fazê-lo (por ex., no mito das raças já apontado). No entanto, não acolhe que aquele que produz bens úteis (discursos ou artefatos) não saiba ou não queira saber sobre o que pratica quanto à sua verdade, verossimilhança ou falsidade e, principalmente, seus fins. O caminho é agora da theoría à práxis: como se faz, por que e para quem se faz.

Dado que há discursos falsos indispensáveis que acompanham a própria poesia, então, qual a verossimilhança e utilidade que ela guarda para que Platão venha a aceitá-la, ou não? É preciso atentar ao modelo e sua imitação, e sendo o poeta um técnico sui generis porque o divino fala por meio dele, não se pode rechaçá-lo sem cuidado. Se não é a verossimilhança a ser censurada, onde recai a censura? Em dois pontos: (a) porque imitam e criam, em palavras e imagens (eídola legóumena), imitações na alma que provocam certas emoções; 
(b) porque se o poeta não procura a verdade (não sendo isso o censurável), acha-se distanciado do real cuidado educativo quanto ao que fala, pois não sabe do que fala ao depositar seu trabalho nas mãos dos deuses sem preocuparse com o tipo de emoção que venha a provocar nos homens; nem se questiona quanto às ações que a técnica do bem falar venha a produzir em cada um.

O primeiro motivo é complexo e núcleo desta investigação: está no campo da crítica platônica à poiésis produtora de emoções e no conhecimento para o agir; o segundo, na sua crítica à educação histórica assentada no século IV a.C., ${ }^{1}$ dependente dos poetas e oradores e suas técnicas, sagradas e nãosagradas, ao discursar e educar os gregos. Nenhum dos motivos é primário quanto à verdade, pois se trata da carência de saber quanto aos próprios fins e ao que venha a provocar no corpo e alma de cada ouvinte.

Se o projeto reflexivo na República é o de uma cidade justa, essa carência é absolutamente inoportuna. A mesma reflexão serve aos discursos sofísticos preocupados em persuadir o grande número por meio de certas emoções. Quanto a estas, sua compreensão está imbricada exatamente na Teoria da Alma platônica, exposta em vários diálogos, e como tripartida na República, o que será em parte aqui abordado. A pergunta que emerge quanto à censura da mousiké e da poesia em particular diz respeito à força dos sons, letras, imagens faladas recolhidas na alma e que a movem para o conhecer e para a prática. De um lado, o que é e a imitação do que é; de outro lado, o conhecimento do que é e a ação produtora e prática quanto ao que é. Há entre os dois aspectos distâncias e proximidades. Tem-se que investigar a questão das emoções que estão passo a passo com os fins da prática poética.

\section{A questão da sensação (aísthesis) e da imaginação (phantasía) ${ }^{2}$}

Um difícil problema é apontado pelos próprios filósofos gregos e alguns recolhedores quanto ao estatuto da sensação, sem o qual, creio, não

1 Não esqueçamos que a Atenas de Platão tem oradores preocupados no aprimoramento da educação já constituída, inclusive com base nos valores passados pelos poetas. Isócrates, por exemplo (no Elogio a Helena e no Panegírico) faz a propaganda do pan-helenismo, e o caráter educativo de seus discursos tem esse propósito: não distanciar-se dos valores da cidade, aprimorar a formação dos jovens por meio de discursos que ajudem a manter a glória dos valores gregos. Diz o rétor ao criticar certos filósofos: "quanto aos que pretendem exortar o equilíbrio e a justiça pode-se ver que meu ensinamento é mais útil e mais verdadeiro do que o deles, uma vez que os deles incitam a uma virtude e sabedoria desconhecida por todos e discutida entre eles mesmos; quanto a mim, falo do que é conhecido por todos" (Panegírico, 84). Por isso, Platão quer transcender os valores cívicos da época e a crítica aos poetas e sofistas tem que estar presente em sua reflexão de modo profundo ao perguntar sobre a téchne e o estatuto da mímesis nessa perspectiva.

2 Sobre esse assunto há dois cuidadosos artigos, elaborados a partir de outro ângulo temático, como o de Graciela Marcos: "Mímesis e ilusiones de los sentidos em República X: Observaciones a la crítica de 
compreenderemos a questão das emoções e a poíesis. É preciso abordar, ao menos parcialmente, parte dele para esclarecer a mimetiké poietiké do livro $\mathrm{X}$ da República, pois é a imitação específica dos poetas que Platão quer criticar. A sensação é já um pensamento? Ou é somente a recepção do sensível (aisthetón) pela via do poder de sentir (aisthetikôn)? Há uma troca entre o que se dá a receber e o que recebe? Ou um se impõe ao outro? Qualquer que seja a resposta, e Teofrasto apontou algumas em sua obra De sensu, sabe-se das conseqüências quanto à afirmação ou negação de uma ou outra possibilidade: ou a sensação é um conhecimento que diz aquilo que é o sensível recebido imediatamente como sensação; ou o sensível se impõe como ele é ao "estetério" e este reproduz, de algum modo especificamente próprio, o páthos recebido, criando uma sensação (aísthesis) que, por si, não é conhecimento.

Aristóteles $^{3}$ assinala que todos os animais têm sensação (aísthesis) havendo os que são dotados de inteligência. Estes podem procurar o saber nas suas práticas, o que os desprovidos de inteligência não podem. Como há movimentos entre o sensível e a sensação que não indicam conhecimento algum, a não ser que se tenha inteligência (noûs), parece faltar um intermediário nesse "processo". Sendo que as sensações são fluxos (assim como a coisa sensível), como se verá, para Platão não se trata de uma perfeita reação de causa-efeito entre ação-paixão com a incidência maior ou menor de um dos lados, mesmo porque nem sempre o que se recebe do sensível é conhecido animicamente, e o que se conhece animicamente não é só a partir do sensível, além de o conhecimento anímico vir a ser no sensível modificando-o inclusive (caso das technaí).

Mas a pergunta principal é sobre se a sensação é um conhecimento (o que é para alguns pensadores), porque se for, (a) o que lhe chega do sensível é já pensado e conhecido enquanto tal (pela sensação como efeito direto do sensível via sentidos), então, a sensação segue o que a afetou (a coisa sensível) de modo que o sentir é sempre verdadeiro, o que um sofista poderia afirmar; porém, (b) se não houver tal garantia, há possibilidade do pensamento falso, como Platão tratou de explorar principalmente no Sofista, dado que entre o

Aristóteles a la phantasía platónica (in Méthexis, XVIII, 2005, Academia Verlag, Alemanha) e Aísthesis y Phantasía em Platón, Teeteto, 184b-186c (in Ordia Prima, Rev. Estudios Clásicos, v. 2, 2003, Argentina). Leia-se, também, os pontos de vista de K. Lycos (Aristotle and Plato on "Appering". Mind, 73, 1964) e A. Silverman (Plato on Phantasia, Classical Antiquity. 10, 1991).

3 In Parva Naturalia, I. O estagirita não parece distanciar-se de Platão quanto à não-exigência de verdade para a poesia, e por vezes a salva, por vezes não, conforme os textos sejam a Poética, a Retórica ou a Metafísica. Leia-se artigo de F. Rey Puente (O philómythos e o philósophos. Kriterion, 102, 2000). Não será aqui analisada a discussão sobre o Anima III, de Aristóteles, e a relação aísthesis-phantasía, objeto de outro estudo em andamento (Cf. nota 6). 
sensível, a sensação e o conhecimento dela incide um processo complexo e não imediato. Com tal proposta, ele pode afirmar a existência do lógos pseudós, contra os sofistas, como é sabido. O ineditismo de Platão está no fato de introduzir uma potência anímica a que nomeia Phantasía, diferente das próprias sensações (aisthéseis) e do lógos no sentido que lhe dá o filósofo.

Tudo indica que ele pretende assinalar uma instância receptora de sensação e produtora de dóxa ao mesmo tempo, cujo poder é receber a sensação e criar uma imagem dela manifestando um conhecimento (um julgamento, uma opinião) sobre tal imagem (dóxa). O lógos e a diánoia sustentam a existência do erro ao usarem seus critérios reflexivos-argumentativos sobre o "material" da phantasía. É o que diz no Sofista. Abordemos brevemente a comentada passagem do Sofista sobre esse assunto.

Logo após suas conclusões quanto à reflexão sobre o não-ser, o estrangeiro é obrigado a afirmar a existência do não-ser como parte do ser, reflexão já apontada em parte e ampliada até $260 d$, o que o obriga a analisar, com cuidado, o que é lógos, diánoia, dóxa e phantasía (260e, 261a et seq.). Do ponto de vista desses modos de agir da alma que conhece, ele dirá, em 263e, que a diánoia (pensamento dialógico e silencioso da alma consigo mesma) e o lógos (pensamento argumentativo emitido pela voz e disposto como afirmativo ou negativo sobre algo) são o mesmo na linguagem usual, bem como o julgamento, ou opinião (dóxa). Afinal, são modos de conhecer por palavras. Em 264a e 264b, respectivamente, aponta:

(...) quando esta (dóxa) se apresenta não mais segundo ela mesma, mas por meio da sensação (aisthéseôs), é correto nomear tal afecção (páthos) com outro nome que aparecimento (phantasían)? (...) e que há o pensamento discursivo verdadeiro (lógos alethés) e o falso (pseudés), e vimos que o pensamento (diánoia) é o dialogo da alma consigo mesma, a opinião (dóxa) é finalização do pensamento (dianoías), e o que dizemos "aparecer" (phaínetai) (é) juntamento (symmeixis) de sensação e opinião (aisthéseôs kaì dóxa), necessariamente parentes do lógos, e são algumas delas verdadeiras e algumas vezes, falsas.

O que significa ter "imagens na alma", ou como dizemos hoje, ter "representações"? Quintiliano, ${ }^{4}$ no século I a.C., considera que "o que os gregos chamam de phantasíai chamamos de visiones, visões imaginativas através das quais as imagens ausentes das coisas são representadas na alma no sentido de que nos parece discerni-las com nossos olhos e tê-las presentes diante de nós." Quintiliano crê que phantasía é visão de imagem que já vimos antes, quer 
talvez de algo aqui e agora, ao qual voltamos as costas (não usamos os sentidos no momento), quer rememorando a coisa ausente, o que tangencia a definição de memória. O sentido platônico é amplo, cabendo à phantasía também as funções apontadas e outras não especificadas pelo recolhedor romano. Os aparecimentos na alma são conjunções de pathémata (afecções) referentes ao aisthetón (sensível), que por sua vez vem a ser aísthesis (sensação) pela via dos sentidos (aistheteríon), como apontado, havendo também pathémata somente da alma, em que a phantasía não tem porque ser ativada. ${ }^{5}$

\section{1}

Parece-me, assim, que é essa a pedra de toque para pensar a mímesis em sentido amplo, na medida em que a phantasía não recebe a coisa sensível como se esta se imprimisse em cera mole, mas é um poder específico com dóxa. Sendo produtora, é demiúrgica: cria imagens, cria duplos de (eidola). Note-se que as traduções usam para a expressão tá dokóunta, por exemplo, a palavra "aparências". Na verdade, é já uma interpretação que necessita de explicação anterior, ancorada que está na phantasía como poder que tem dóxa e cria imagens, de modo que as coisas que "aparecem" à alma como imagens fazem supor que saibamos delas e que ocorrem em nós juntamente com um julgamento sobre elas, uma opinião imediata da ocorrência. Tal opinião pode ser verdadeira ou não, não importa nesse grau do conhecer. Só secundariamente podemos julgar com mais firmeza: "vejo algo azul" (phantasía); se é ou não verdadeira tal opinião, isso dependerá do poder do lógos-diánoia para se saber por meio de outro movimento anímico.

Traduzir tá dokóunta por aparências não ajuda muito o estudioso. O que garante um julgamento verdadeiro com relação aos aparecimentos "sensóriosimagéticos" é o pensamento discursivo que afirma ou nega algo como " $\mathrm{x}$ ", dialogicamente (conforme citação acima). Platão deixa emergir o movimento complexo para que tal poder venha a recepcionar e julgar re-presenças, e dado esse ângulo interpretativo creio difícil aceitar também a tradução de aísthesis por percepção. Perceber é, talvez, ação da própria phantasía (que não é uma sensação), é ter imagem de algo e saber que se tem uma imagem opinável, de uma só vez. Sensação não implica em julgamento, não é pensamento, mas ativa o sensório a ser apresentado e julgado pela phantasía.

O que se poderia chamar de Estética platônica implica, exatamente, no recebimento de pathémata, em como são recebidos, combinados, mimetizados, 
julgados. ${ }^{6}$ As "percepções", ou imagens opináveis, exatamente porque re-presenças não são mais as próprias coisas, é evidente, e ao sinalizarem uma sýmmeixis dizem do parentesco entre phantasía, dóxa, lógos e diánoia, de um lado; de outro lado, o páthos que vem pelo sensível-sensação não é dito em parentesco com o lógos em nenhum texto platônico.

Seguindo um pouco mais a investigação, sabe-se que o "imaginar/ representar" não deixa de ser, portanto, imitação, uma vez que aquilo que percebemos sensorialmente são eikona do que nos afeta. Não é sem razão que a passagem citada, do Sofista, é difícil de compreender. Se o aisthetón (o sensível) tem poder de impor-se e nós temos o poder de recebê-lo como sensação (aísthesis), e a phantasía tem o poder de re-apresentar tal recepção como imagem ou aparecimento com dóxa, ela é a força anímica das imagens (daí a tradução por Imaginação sem maiores explicações). ${ }^{7} \mathrm{O}$ movimento do que nos chega e afeta, e o que retemos e sabemos sobre ele, faz supor um processo até que se tenha um julgamento sobre algo "visto" na alma: se de fato me apareceu algo existente, se é minha criação, se posso ou não dizer do seu tamanho, forma, conteúdo etc. com precisão. Algumas passagens das Leis, Timeu Teeteto, República, e que pontuo sem aprofundar, pois falam por si, podem explicitar o que venho afirmando.

Nas Leis (893c, 894a), Platão diz quanto à gênese das coisas que ela se dá por movimentos de deslocamentos e transformações contínuos entre elementos, por divisões e combinações que fazem nascer compostos tridimensionais: "quando e em que condição se dá a gênese de toda coisa? É claro que se dá quando um princípio, recebendo incremento, passa à segunda transformação e desta àquela mais próxima, ou seja, forma de sensação colhida pelos que sentem (aísthesin schê tois aisthanoménois)." 8

No Timeu, (61bc et seq.) afirma que o duro, o brando e outros contrários, como pathémata se originam de "marcas, impressões, sinais" na alma, os quais nomeamos como se fossem um substantivo (e não são), e que essas marcas vêm a ser de múltiplos modos conforme os primeiros elementos se movimentem entre si mesmos (de modo rápido, lento, para cima, para baixo,

6 Este assunto é parte de outro texto a ser publicado pela ed. Loyola. Nele investigo com mais profundidade a questão da sensação, da phantasía e dos pathémata a partir do Timeu, de Platão, inclusive o estatuto do "semelhante atrai semelhante" aceito também por Aristóteles e difícil de compreender no De Anima III.

7 Esta interpretação não crê possível traduzir aísthesis por percepção, como faz Cornford e os que seguem seu caminho, em geral tradutores e estudiosos de língua inglesa ou seguidores.

8 Evidentemente, não ajuda o leitor a tradução de R. G. Bury (ed. Loeb, Harvard e Cambridge): “(...) e chega à segunda transformação, e depois à próxima e, em chegando à terceira admite a percepção pelos percepcientes". 
etc.), bem como de suas figurações e composições. ${ }^{9}$ No Teeteto, aponta, com insistência, quanto às "qualidades" ou afecções aderidas às coisas que vemos e que podem ser ou não essenciais a elas. Por exemplo, o doce e amargo de uma fruta para quem está enfermo, ou o vento frio-quente-úmido-seco para uma mesma pessoa e as diferentes sensações que temos de um só acontecimento em função de nosso próprio estado. Cito parcialmente a passagem 156e, 157a: "O duro e o quente e demais afecções (pathémata) devem ser concebidos de igual maneira; em si e por si mesmos (...) nada são. De sua aproximação recíproca é que as coisas nascem de toda espécie de movimento".

Na República, no livro VI (506 et seq.), ao explicitar sua reflexão sobre o mégistos génos (Bem), usa da metáfora do sol para mostrar uma "física da visão", ao modo de uma física corpuscular que será aprofundada no Timeu. O que nos chega - e suas qualidades - dependem, então, de muitos movimentos em ajuste, e o que sentimos do sensível não está imediatamente ligado ao modo como ele é, o que para os estudiosos de Platão não é algo novo. Lembro que Aristóteles, bem como alguns filósofos anteriores a Platão, recolhidos por Teofrasto (De sensu), são comparados entre si nesse assunto, como Empédocles e Demócrito. Diz Teofrasto sobre Demócrito que ele crê que corpúsculos indivisíveis chegam à alma e aí se apresentam segundo o próprio modo de ser de cada um, dependendo de sua figuração, tamanho, peso, posição e ordem, e formariam em nós as múltiplas afecções sensoriais, que, por termos também figuração, tamanho, peso, posição e ordem determinados, podemos recebê-las de múltiplas formas.

Empédocles está também nesse caminho: trata-se de afirmar certos ajustes entre corpúsculos, sobre seus encontros, combinações e desajustes ( $D e$ sensu, 60a et seq.), algo que Platão não negaria; ao contrário, é herdeiro de tais reflexões. Empédocles diz que nossos sentidos se adaptam à variabilidade do modo de ser do que nos chega e à variabilidade de nossos póroi (De sensu, 60a7 et seq.). Nenhum desses dois filósofos (para ficar só nestes) deixou de levar em conta as transformações entre o que nos afeta e o modo como nossos órgãos sensórios recebem, bem como a formação de nossas sensações e as represenças que podem ou não ser conhecidas - apesar de ser Platão a especificar essas instâncias, dar ao físico a ponte para o anímico, que conhece pela via da phantasía, e aprofundar o conhecimento verdadeiro ou falso que podemos ter. Aristóteles, que em geral é lido um tanto afastado de Platão, diz no seu Parva Naturalia (tratado I, livro II, 437a,15-22): 
Sobre a potência que possui cada um de nossos sentidos (tôn aisthèseôn hekástê), falou-se antes. Quanto às partes do corpo que vêm a ser naturalmente como sentidos (aisthêtêríois), alguns investigam segundo os elementos dos corpos (énion mèn dzêtoûsi katà tà stoicheîa tôn somátôn); não encontram boa saída quanto a serem quatro (elementos) e cinco aqueles (ouk euporoûntes dè pròs táttara pént'oúsas sunágein).

No De Anima, III (3, 428a, 25) criticará, no entanto, a noção de phantasía platônica, porém o faz do ponto de vista do conhecimento possivelmente verdadeiro, e só deste, que é o que o preocupa na crítica. ${ }^{10}$ Mas Platão amplia a questão ao indicar, também, o processo físico-anímico, além de apontar os problemas que o próprio Aristóteles aponta quanto a possíveis discrepâncias entre aísthesis, phantasía e lógos-diánoia. Como ele está no ângulo da busca da verdade, poderá dizer que se alguém vê algo contrário ao que "sabe" que é, há engano quanto à mescla de aísthesis-phantasía, de modo que tal mescla é criticável quanto à verdade. Assim, se vejo Teeteto ao longe e o reconheço pela imagem que vejo e de onde vejo, mas ao final não é Teeteto realmente quando já está perto, julgo contra a imagem que afirmei antes como sendo Teeteto. A distância entre a imagem percebida como tal e o conhecimento correto é marcada pelo estagirita como um problema platônico. Não o é. Sabe-se que Platão não discordaria de tal possibilidade, e, de fato, aventa a questão nos livros II, III, VII e X da República ao falar das ilusões da mousiké, especificamente da poesia (e também no Teeteto, como se sabe). Considera Graciela Marcos $(2005)^{11}$ a respeito, e a meu ver com razão, que

Platão não revela interesse em explicar a situação de um percipiente em posse de uma opinião verdadeira sobre como é verdadeiramente algo, e graças a isto não se deixa iludir pelo que lhe oferecem os sentidos, como Aristóteles dá por pressuposto no curso de sua crítica (...). Longe de reconhecer, como seu discípulo, uma afinidade natural do homem com a verdade e um acesso relativamente simples a esta, Platão carrega nas tintas contra a tendência para ceder ao testemunho dos sentidos e a persistir no erro, tendência que se encontra fortemente arraigada na maioria dos homens.

Voltando à primeira citação de Aristóteles, no Parva Naturalia, ${ }^{12}$ ele descreve como pensa dar-se o processo de junção dos elementos das coisas e dos nossos sentidos (Estetério) para, logo depois, em 438b (15-30), concluir

10 Cf. estudiosos de Aristóteles que concordam com esse ângulo (veja-se, entre outros, o cuidadoso recolhimento do status questiones de Hans J ürgen Horn (Aristote, Traité de l'âme, III, 2 et le concept aristotélicien de phantasía. Les Études Philosophiques, avr./juin 1988).

11 Cf. nota 5 (p. 61).

12 A discussão de Aristóteles com seu mestre no De Anima não pode ser expandida neste texto, dado o ângulo temático escolhido e sua extensão. Será objeto do ensaio indicado na nota 6 . 
que há uma adaptação entre as duas instâncias, a que afeta e a afetada. Parece claro que a coisa sensível não é exatamente como a recepcionamos e, se o que nos chega depende de várias instâncias, é preciso agora compreender as emoções provocadas pelas sensações e percepções, nosso ponto central, pois já é possível adentrar no campo propriamente anímico e seus pathémata para compreender melhor o livro $\mathrm{X}$ e a crítica à poesia.

\section{Formas da alma e poesia}

Ao poeta, ao legislador, ao retórico, não se exige o saber sobre a gênese em seus meandros, de modo que criam com seus lógoi "opiniões emocionais" pela via das afecções, sensações, percepções, sem a pergunta sobre os princípios. Se o musicista é capaz, conforme o livro III da República, de emocionar os homens para a tristeza, para a alegria, exaltar os ânimos na guerra ou provocar indolência sem nada saber sobre o fundamento de sua arte e seu poder nas ações humanas - poder que se apresenta primariamente "físico" em interação com o anímico -, do mesmo modo, a poesia stricto sensu também nada sabe quanto às suas imagens faladas e emoções que provoca. Ora, se o poeta não sabe sobre o educar, mas é considerado a fonte da Paidéia grega, para a cidade justa en lógos deve curvar-se àquele que sabe sobre os princípios e fins, quer ontológica, quer ética e politicamente. Ao menos se quiser uma cidade justa.

Nos primeiros livros da República, o filósofo afirmara a alma com três formas ou dynámeis (epithymétikón, thymoeidés, logistikón), em acordo com os três estamentos da cidade e com as excelências exigidas de cada estamento e de cada cidadão. No livro X (604e), dirá que a poesia toca o aganaktetikón, um outro nome para a forma animosa ou impulsiva da alma (thymoeidés). Nesse livro, Platão reflete a partir de duas partes da alma (sem negar as três potências anteriores): a lógica e a alógica. Para ele, o poeta pode dizer coisas belas e ao mesmo tempo falsas, não havendo problemas quanto a isso, como já indicado, porém, é custoso afirmar que a areté, a excelência de um poeta, vai a par e passo com a ilusão e o poder animoso, mas assim é (602d):

E as mesmas coisas nos parecem quebradas ou retas segundo o que vemos na água ou fora dela, côncavas ou convexas conforme a vagueza da visão através das cores. Então, tudo isso lança a alma em perturbação; e à natureza dessas nossas impressões é que a pintura sombreada, em nada distante da magia, como a arte do maravilhoso e outros muitos artifícios, se aplicam e se dirigem.

Diante dessas incertezas das impressões que nos chegam e nos confundem - e sabemos que tais ilusões são dependentes do modo de ser de cada coisa, de 
nossos órgãos sensórios, de nossa phantasía e do lógos-diánoia -, o logístico deve cuidar de controlar tal vagueza usando do que lhe é mais próprio: da medida, do número, do peso, para que os aparecimentos vagantes sejam bem colocados pelo saber afetivo-prático (603a). O que ele afirma no Timeu (43c,d), quanto às agitações da alma diante do que lhe chega pela via do corpo, auxilia a compreensão desse momento da República:

nesse corpo a que aflui e onde flui uma agitação ininterrupta, eles (os deuses) introduziram os movimentos periódicos da alma imortal. Mas estes movimentos submergidos nela, não os dominava, nem era por eles dominada (...). De modo que o Vivente todo inteiro se movia, sem dúvida, mas avançava sem ordem e alogicamente, ao acaso.

Essa descrição é a mesma das emoções que transtornam o movimento medido e ordenado (periódico) do logístico. Imagens e palavras provenientes de sensações-percepções afetam as três potências da alma de diversos modos, pois diversos são os modos de ser de cada potência em relação com o que as move. O filósofo da República parece ser o vigilante das percepções e emoções que nascem nos cidadãos, dando-lhes, na medida do possível, certa ordem e medida necessárias, uma vez que as ilusões criam toda espécie de artifícios e maravilhas - mas são ilusões, o que não é dito pelo seus demiurgos. Se nos deleitam, muito bem, mas precisamos saber que são ilusões, artifícios, se somos cidadãos justos. E aquele que as cria também, porque são cidadãos.

As potências da alma indicam as forças que temos de sentir e desejar, dispor-se a, ter certas emoções, estar em estado de prazer e dor etc., mas só o logístico pensa sobre tais acontecimentos com critérios, ao contrário dos animais que não o tem. Se considerarmos o item anterior (3) quanto ao processo da sensação-percepção, algo mais se expõe quando o filósofo afirma, em 602e: "o que julga em nossa alma contra a medida não pode ser a mesma faculdade que julga segundo a medida (Tò parà ta métra ápa doxádzon tês pchychés tò katà ta métra ouk án eín tautón)." Ou seja, diz que as sensações-percepções, quando sem julgamentos de valor (função do lógos argumentativo), ficam à mercê das potências da alma que estão separadas dele, porque não têm funções lógicas, mas outras. No caso, trata-se do epithymetikón e do thymoeidés. Diz mais, que a mimética é criticável (do ângulo da verdade ou falsidade) porque tem grande distância da verdade (os graus distanciados do modelo conforme expostos no livro X) e também do poder mais nobre (kyriôs) da alma - que ele nomeia, em $603 \mathrm{~b}$, de phronéseôs. Essa distância estabelece camaradagem e amizade com a parte da alma que nada tem de verdadeiro e também nada 
de bom equilíbrio (hygiei - 603b). ${ }^{13}$ Trata-se do poeta e do uso prioritário do thymoeidés (603c-604d) como potência que pode ser preguiçosa e amiga da moleza (604d), ou irritável quando não ouve o logístico.

Ainda que o filósofo exponha a poesia como longe da verdade - e ela está -, o importante é que esse demiurgo não apresenta nenhuma "tendência filosófica", como os philakôs do livro II, que usam a potência timocrática mais que as outras e não são tão criticados. Mas, os philakôs se curvam aos reis-filósofos, verdadeiros guardiães. Por que não se curvaria o poeta? Nesse contexto, deve-se indagar o que seja o phroneseôs ${ }^{14}$ para saber o que significa a distância dos poetas dessa parte da alma. É o aspecto do logístico "o mais nobre", o que tem o poder senhorial, que pensa e julga os sentires, as percepções, exatamente o que nos chega por impressões sensíveis (páthos+aísthesis) reapresentadas na alma (phantasía) e suporte de nosso pensar prático.

Assim, tudo indica que a mimética poética é criticável porque o logístico do poeta "não ouve" o pensar prático (phroneseôs), e não porque venha a dizer falsidades. O phroneseôs só é atualizado diante das afecções-sensaçõesrepresenças e diz respeito à prática; é ação do logístico, sim, e dependente desse "material" sobre o qual se debruça a alma reflexiva para fundar o bom agir. Não há epistéme (como conhecimento verdadeiro) para as ações práticas - o que pode experimentar o rei-filósofo -, mas há a ação reta (kath’orthós) para todos, que é dita por Platão (e também por Aristóteles) prática sábia (phrónesis). A esse saber agir o poeta não atenta, mas todos os técnicos da República têm que atentar. Sem a areté de todos não há justiça, ou, em outras palavras, sem a transformação de cada um a partir de um bom modelo não há o melhor para todos nem para cada um. Só o phroneseôs possibilita isso.

Já se pode afirmar com mais clareza que no início: a crítica platônica à imitação poética é uma crítica ético-política e não epistemológica, no rigor dos termos. O poeta manipula, sem saber que o faz, as emoções, as imagens, o saber prático dos homens. E, para Platão, assim viveram as cidades e vivem à sua época, pois educadas pela poesia (acrescente-se, ainda, oradores,

13 Em geral, hygiés é traduzido por "são", quando relacionado ao corpo (corpo saudável). No caso, sendo relacionada à alma que conhece, preferi que permanecesse o sentido de "bom equilíbrio"(seria "higiênico" ou "bem ajustado". Platão teria a palavra pháulos para o nosso insensato, e assim se costuma traduzir, e não a usa. As traduções carregam nas tintas quando preferem a palavra "perverso-perversidade" nessa passagem.).

14 A raiz da palavra é do verbo phroneîn, traduzido normalmente por pensamento ou reflexão (aprofundei esse estudo no texto "Consideraciones sobre la psyché en el libro VII de la República: el logistikón del dialéctico" (in Los símiles de la República de Platón VI-VII, R. Gutiérrez (Org.), PUC-PE, F. Editorial, 2003). Phroneseôs implica a ação do phronésai, instância do logístico a que Platão dá grande importância e costuma passar desapercebida nas interpretações (Cf. livro VII, 530b et seq.). A phrónesis depende muito desse poder anímico. 
logógrafos, sofistas) que não sabem sobre os fundamentos da Paidéia que veiculam. A ontologia serve ao filósofo como direção primeira para a "crítica prática" e para uma teoria nova sobre a alma. Afinal, a "matéria" do poeta é a multiplicidade de formas para a qual ele tende e que facilmente re-produz sem critérios, no dizer de Platão, pois é essa a inclinação do aganaktetikón, isto é, do que em nós tem a força de irritar-se, de indignar-se, de querer aplausos, de impulsionar-se sem fins claros.

Ora, bem se sabe que tais impulsos do timocrático, inerentes à nossa vida e indispensáveis para o humano, não servem de conselheiros para a boa prática, pois que não distinguem bem, não separam bem, muito menos educam bem. Assim, o poeta figura-se um ser que, além de participação com o divino tem o thymoeidés acirrado. A combinação entre sensação, percepção, pensamento, emoções e ações pressupõe o uso aleatório das eídola legóumena que comovam de modo específico, ajustadas à cidade justa. Os poetas têm como modelo as Musas e o sensório-perceptivo, porém, passam por censura. No primeiro caso, a pretensa verdade das eídola legóumena é replantada no não-sagrado pela via da manía. Platão não nega tal possibilidade, mas como as Musas por vezes dizem verdades e por vezes falsidades, como lhes aprouver, como já adiantara Hesíodo na Teogonia, não é possível seguir o acaso nessa matéria.

Inserido na cidade justa e devidamente censurado no que deve ser, o poeta terá que adequar-se aos fins para que sua arte seja compreendida como éticopolítica. Não é algo que a modernidade desconhece, para o bem ou para o mal.

\section{Referências}

FATTAL, M. Lógos, pensée et verité dans la philosophie grecque. Paris: Harmattan, 2001.

FATTAL, M. La philosophie de Platón. Paris: Harmattan, 2001.

GUTIERREZ, R. (Org.). Los símiles de la República de Platón VI-VII. Lima: Fondo Editorial (PUCPE), 2003.

HALLIWELL, S. The aesthetics of mimesis. Princeton: Princeton Univ. Press, 2002. HORN, H. J. Aristote. Traité de l'âme II,3 et le concept aristotélicien de phantasía. Les Ėtudes Philosophiques, avr./juin 1988.

KRAUT, R. (Org.) Plato. Cambridge Univ. Press, 1992.

MARCOS, G. Mímesis e ilusiones de los sentidos em República X: Observaciones a la crítica de Aristóteles a la phantasía platônica. Méthexis 18, 2005.

PUENTE, F. R. O philómythos e o philósophos. Kriterion, 102, p. 128-135, 2000. 